Volume: 12 Issue: 1 Year: 2015

\title{
The sources of self-esteem: Initating and maintaining romantic intimacy at emerging adulthood in Turkey
}

\author{
Nilüfer Özabacı ${ }^{1}$ \\ Ali Eryılmaz ${ }^{2}$
}

\begin{abstract}
This study examines the relationship of emerging adults' in initiating and maintaining romantic intimacy with sub-dimensions and explores the extent that self-esteem in emerging adults could explain the initiation and maintenance of a romantic relationship. The participants included 136 male and 106 female totaling 242 university students. In order to collect data, Rosenberg Selfesteem Scale, Markers of Starting Romantic Intimacy Scale and Quality of Relationship Inventory were used. According to the results, emerging adults perceived both having markers of starting romantic intimacy and the positive quality of relationship as significant sources for their selfesteem. The results of the present study emphasize the significance of self-esteem for starting and maintaining romantic intimacy.
\end{abstract}

Keywords: Adolescence; emerging adulthood; relation; relationship quality; romantic intimacy; self-esteem

\section{Introduction}

The process of identity formation consists of experience and decision making in different situations over many areas of life. Particularly, experience at love, work and worldview as well as decision making begins during adolescence, then becomes more evident at emerging adulthood (Connely \& Goldberg, 1999). Romantic relations, a significant experience during emerging adulthood, also help with identity and intimacy formation within developmental context (Sanderson \& Cantor, 1995). Along with romantic relations come emotions and behaviors that include a feeling of intimacy for someone else, receiving support from others and a feeling of security. Moreover, it comprises the idealized emotions and behaviors like the romantic relations between the young, admiration and infinite love for partners (Fischer \& Alapack, 1987; Gray \&

\footnotetext{
${ }^{1}$ Ph.D. Professor, Osmangazi University, Faculty of Education, niluferozabaci@, hotmail.com

${ }^{2}$ Associated Professor, Osmangazi University, Faculty of Education, erali@hotmail.com
} 
Özabac1, N., \& Eryllmaz, A. (2015). The sources of self-esteem: Initating and maintaining romantic intimacy at emerging adulthood in Turkey. International Journal of Human Sciences, 12(1), 178-191. doi: $\underline{10.14687 / \text { ijhs.v12i1.3014 }}$

Steinberg, 1999; Bradbury, Cohan, \& Karney, 1998; Gottman \& Levenson, 2000). Once romantic identity begins to take shape, emerging adults are thought to become increasingly motivated to convey their 'true selves' to a partner. Yet emerging adults are challenged in this regard as they feel they must fulfill their need for autonomous self-expression while still remaining connected (Connolly \& Goldberg, 1999). In sum, the notion of identity and autonomy are consistent with the "independence processes" highlighted by Collins and Steinberg (2006) in their recent treatise of interpersonal relationships.

Fisher, Aron, Mashek and Brown (2002) emphasized that humans are programmed to establish and maintain personal relations in order to survive and reproduce (Fisher 2006). The biological structure provides that the young and young adults look for a partner on the basis of romantic relations. As a result of this programming, individuals are prone to start a romantic relationship. With respect to starting romantic intimacy at emerging adulthood, Eryllmaz and Atak (2011) highlighted five important factors, namely 1) self-perception, 2) self-knowledge, 3) behavioral intimacy, 4) cognitive and emotional intimacy, and 5) romantic verbalization. Emotional and cognitive intimacy include empathy, thinking about the other person and expressing feelings, while behavioral intimacy involves spending time with the loved one. On the one hand, self-perception refers to the individual's evaluation of self in relation to the characteristics of sympathy, attraction and cleverness in the context of romantic relationship. On the other hand, self-knowledge includes characteristics such as honesty, respect for the others' feelings and opinions during the relationship. Lastly, romantic verbalization includes variables such as writing poems and verbalizing or sharing meaningful communication (Eryllmaz \& Atak, 2011).

According to developmental theorists (Connolly \& Goldberg, 1999; Furman \& Wehner, 1994) the initiation of a romantic relationship in emerging adulthood is propelled by the combination of a young person's emerging awareness of sexuality with a heightened need for intimacy and affiliation with non-familial others. The sexual needs of emerging adults are thought to include the feeling and expression of passion, desire, and sexual attraction, as well as the possibility of participating in sexual activity with a partner, even if the full range of these behaviors is not realized (Hatfield, 1988; Tolman, 2002). The need for romantic intimacy has been defined in terms of establishing a high degree of emotional closeness with a partner, supported by such processes as trust, understanding, disclosure, and the mutual expression of loving feelings (Collins \& Sroufe, 1999; Connolly \& Goldberg, 1999). Empirical studies of emerging adults and their view and concept of romance have highlighted very similar processes and themes (Feiring, 1996; Shulman \& Scharf, 2000; Tolman, 2002). Most teenagers believe that romantic relationships are triggered by strong passionate desire 
Özabac1, N., \& Eryllmaz, A. (2015). The sources of self-esteem: Initating and maintaining romantic intimacy at emerging adulthood in Turkey. International Journal of Human Sciences, 12(1), 178-191. doi: $\underline{10.14687 / \text { ijhs.v12i1.3014 }}$

and attraction. Adolescents also report that romantic relationships provide them with companionship and closeness.

Attraction has evolved to enable individuals to select preferable potential mating partners and to motivate them to focus their courtship attention on these individuals, thereby conserving courtship time and energy (Fisher, 1998; Fisher et al., 2002). Individuals reporting feelings of attraction experience a host of labile psychophysiological responses such as exhilaration and euphoria. The other experience of love termed as attachment or companionate love (isher, 2006) is characterized by maintenance of proximity, affiliative gestures, and expressions of calm and content when in contact with the long-term mating partner. Similarly, within the framework of marital relationships and social psychology, adult as well as adolescent romantic relationships have been conceptualized in terms of affiliation, intimacy, attachment, and commitment (Furman, Brown, \& Feiring, 1999; Shaver \& Hazan, 1988). Intimacy leads to a deeper and more committed form of relationship (Connolly \& Goldberg, 1999). In turn, the presence of commitment leads to long-term relationships thereby enhancing the bonding between partners, expressing deeper levels of caring for each other ( $\underline{\text { Brown, } 1999})$ and laying the foundation for the optimal development of potential offspring (Fisher, 2006).

In the literature, self-esteem is one of these factors. The concept of self-esteem is defined as a person's developing a positive attitude toward himself. The effect of self-esteem on maintaining and on ending a romantic relationship has been most frequently explored. The studies so far have revealed that self-esteem is a crucial factor for a healthy relationship (Hally \& Pollack, 1993). Furthermore, it has been stated that self-esteem has a facilitating effect on maintaining sexual intimacy, thus the relationship. It was found that individuals, who reported more of a need for recognition, had lower self-esteem levels (Cramer, 1993). On the onset of a romantic relationship, it was also found that self-esteem has an important effect on self-perception and self-knowledge (Erylmaz \& Atak, 2011).

Self-esteem is an important factor for maintaining a relationship. In a romantic relationship, when an individual feels well understood, unique and accepted by their partner the romantic relationship becomes more positive (Meador \& Rogers, 1979). In that sense, self-esteem is considered a notable factor for maintaining the relationship (Hally \& Pollack, 1993; Cramer, 1993). Conversely, a low level of self-esteem is one of the important reasons for breakdown of the relationship (Chain, 1988).

The results of the studies on interpersonal relations have revealed that trust, social support, and the depth of relationship are the main components that determine the quality of the relationship. In 
Özabac1, N., \& Eryllmaz, A. (2015). The sources of self-esteem: Initating and maintaining romantic intimacy at emerging adulthood in Turkey. International Journal of Human Sciences, 12(1), 178-191. doi: $\underline{10.14687 / \text { ijhs.v12i1.3014 }}$

particular, both social support and trust are significant aspects of friendship and companionship in both business relations as well as romantic relations ranging from flirting to marriage. These qualities are also considered preconditions for maintaining the relationship. Most studies have focused on the quality of the relationship with the ones in our immediate surroundings. Social support, which is crucial for this relationship, is defined as the situation that provides transitions between the activities involving life problems, obstacles, responsibilities and stress and that determines the quality of the relationship during the maintenance process. There are three categories for criteria of social support: 1) the "social relationship" criterion determines the individuals' integration into a group and interpersonal relations within group, 2) the type of support criterion is "received support", which refers to the support received from others within a special time period, and 3) "perceived support" is the support that a person believes to take when necessary Studies on relationships have put forth that the support partners provide for each other influence the results of the relationship. Moreover, social support, common interest, and the depth and features of the relationship, which are main sources of appeal between couples could turn into disappointment and stress with time (Scharf \& Scharf, 1997).

The quality of a romantic relationship is often indicated by the sense of passion, love or intimacy between partners, however, the importance of the partners' ability to withstand differences and resolve them successfully cannot be underestimated. It is important to acknowledge that it takes time for a romantic encounter to develop into a sustained and balanced relationship ( $\underline{\text { Brown, }}$ Feiring, \& Furman, 1999). It can be assumed that the balancing of self and the other's needs are different in the initial and latter stages of a relationship. For example, collaboration for mutual interest (Selman, 1980) is more relevant in a lasting relationship than in an interaction that is not sustained. Conceptually, this raises the question of whether or when romantic encounters become relationships, namely when partners become capable of addressing differences, resolving them, and as a result deepening the sense of closeness. An interaction (or an attraction) between two partners is not a relationship. Only when encounters between two persons are sustained do they become relationships that involve rule governed interchanges over an extended period of time (Hinde, 1997).

Therefore, it should not be overlooked that disagreement and conflict are a part of romantic relations. Adolescents report conflict with their close friends once or twice a day (Laursen, 1993). It is considered that conflict in a relationship give implication to the quality of the relationship while at the same time they guide conflict coping skills within the relationship (Perry, Perry \& Kennedy, 1992). 
Özabac1, N., \& Eryllmaz, A. (2015). The sources of self-esteem: Initating and maintaining romantic intimacy at emerging adulthood in Turkey. International Journal of Human Sciences, 12(1), 178-191. doi: $10.14687 /$ ijhs.v12i1.3014

In recent years, development psychology literature has offered some explanations suggesting that individuals do not mature directly from adolescence to adulthood; rather, they experience a preparation period before the transition to adulthood (Arnett, 2000). For instance, socio-economic changes recorded over the last five decades have been found to have some reflections on individuals' transition from adolescence into adulthood. In this process, it has been revealed that individuals postpone developmental duties such as getting married, becoming a parent, completing their education, and living in a separate house until the end of their 20s (Arnett, 2001;). Arnett (2000; 2004) labels the period that individuals experience after adolescence and before adulthood as "emerging adulthood".

The romantic relationships at emerging adulthood, during which identity is being discovered, play important roles in the development of individuals. The studies conducted on romantic relationships during this period (Connolly \& Konarsky 1994; Furjman \& Schaffer 2003) revealed that romantic relationships have a significant effect on the emerging adults with regard to development of essential behaviors for better adaptations to life.

Consequently, self-esteem is a crucial indicator for the positive course of a relationship. Moreover, self-esteem can heighten by means of their relationships. Thus, an individuals' selfesteem improves with support factors including that of starting and maintaining romantic intimacy. To conduct an empirical study on such a mutual connection, which has been handled mostly theoretically, could contribute to the literature. As a result, the aim of the present study is to determine the connection between emerging adults and the initiating and maintaining of romantic intimacy with its sub-dimensions, as well as examine to what extent the self-esteem of emerging adults explains the initiation and maintenance of romantic relationship quality.

\section{Method}

\section{Participants}

In the selection of participants for the present study, maximum variation sampling approach was utilized and purposeful sampling method was used. In purposeful sampling, the researcher selects a sampling group on the basis of theoretical knowledge, his or her own experience and the objective of the study. Researcher define the criteria for population.

In that context, for the present study and considering the representation of the population, the criteria adapted for this study included having a university education and being within the age range of 18 to 27 years. Accordingly, the students attending Osmangazi University in the 2010- 
Özabac1, N., \& Eryllmaz, A. (2015). The sources of self-esteem: Initating and maintaining romantic intimacy at emerging adulthood in Turkey. International Journal of Human Sciences, 12(1), 178-191. doi: $\underline{10.14687 / \text { ijhs.v12i1.3014 }}$

2011 academic year comprised the sample for this study. The participants selected through this sampling method include 136 male (56.2\%) and 106 female (43.8\%), totaling 242 university students, who have an average age of 21,75 out of the 18-27 year age range and with 1,55 standard deviation. The participants participate to research voluntarily. Out of the participants, 131 students $(54.13 \%)$ were enrolled in the sciences while 111 students $(45.87 \%)$ were enrolled in the social sciences. In terms of years, 37 participants (15.29\%) were first year students, 10 of them $(4.13 \%)$ were in their second year, 73 participants $(30.16 \%)$ were third year students, and 113 participants $(46.69 \%)$ were fourth year students, and lastly 9 of them $(3.73 \%)$ were in their fifth year.

\section{Ethics}

All ethical standards were considered. The Heads of Departments gave permission for data collection. All participants voluntarily took part in the study. Fifteen individuals did not agree to participate in the study.

\section{Data Analysis}

This study was conducted as a relational screening model. The dependent variable of the study is self-esteem while the independent variables are the use of markers for starting romantic intimacy and the quality of relationship. The relationship between the dependent and independent variables was examined through Pearson Correlation Analysis. Additionally, multiple regression analysis was used to examine the correlation between self-esteem, starting romantic intimacy and quality of relationship.

\section{Instruments}

For data collection, Rosenberg Self-esteem Scale, Markers of Starting Romantic Intimacy Scale and Quality of Relationship Inventory were used.

Rosenberg Self-esteem Scale (RBSÖ-Rosenberg Self-esteem Scale). This scale was developed by Rosenberg (1965). It consists of 12 sub-dimensions with 63 multiple choice items. For this study, self-respect sub-dimension category was used. This category includes 10 items; 5 of which were affirmative while 5 items were negative on 4-point Likert scale (Rosenberg, 1965). The scores are between $0-40$. To have a high score from the scale implies high self-respect level. This scale was adapted for Turkish culture by through psychiatric interviews in order to test the validity of selfrespect category. In that study, the students' self-respect was categorized as high, average or low according to their opinions about themselves and the results indicated that the validity rate was .71 . 
Özabac1, N., \& Eryllmaz, A. (2015). The sources of self-esteem: Initating and maintaining romantic intimacy at emerging adulthood in Turkey. International Journal of Human Sciences, 12(1), 178-191. doi: $\underline{10.14687 / \text { ijhs.v12i1.3014 }}$

The test-retest validity coefficient was calculated as .75. For the present study and for these participants, the reliability of the scale was found as .83 .

Markers of Starting Romantic Intimacy Scale (RYBBÖ). This instrument was developed by Eryllmaz and Atak (2009) as a five-dimensional scale designed to measure an individuals' perceptions related to starting romantic intimacy. Achieving a high score on the scale means reporting markers of starting romantic intimacy and the ability to start romantic intimacy. This 4-point Likert scale enables analysis with either sub-dimensions or total score. The sub-dimensions of the scale are: 1) self-knowledge, 2) self-perception, 3) behavioral intimacy, 4) emotional and cognitive intimacy, and 5) romantic verbalization. The scores from the scale vary between 17 and 68. During the development of the scale, exploratory factor analysis was used to examine the factor structure of the scale. The five sub-dimensions explain $61.72 \%$ of total variation. The internal consistency reliability of the entire scale was calculated as .83 while for the sub-dimensions, it was found between .55 and .79 . Additionally, the test-retest reliability coefficient of the scale was found as .83 . For the present study and participants, the reliability of the scale was obtained as .84 .

Furthermore, for the adaptation validity, this scale was applied to 218 university students and within that context, life satisfaction and impulsivity scales were used. According to Pearson Correlation Analysis, the Markers of Starting Romantic Intimacy has significant positive and low level correlation with life satisfaction scale $(\mathrm{r}=.20 ; p<0,01)$ while with impulsivity scale, significant negative and low level correlation ( $\mathrm{r}=-.19 ; p<0,01)$ (Eryllmaz \& Ercan, in press).

Quality of Relationship Inventory. This scale could be used to evaluate all the close relationships of an individual. In this study, the definition of a romantic relationship was provided at the beginning of the inventory. Then, the participants were asked to think about romantic relations and their partners. So, they were asked to answer the items in the scale considering only their romantic relations.

This scale was developed (Pierce et al., 1991) to evaluate an individual's close relations in terms of social support, quality and conflict. The reliability of the scale varies between .81 and .93 . The test-retest reliability coefficient differs in between .48 and .79 (Pierce et al., 1997). The adaptation of the scale into Turkish was conducted by Özabac1 (2011) with confirmatory factor analysis.

Each item on this scale rates from 1 (none) to 4 (a lot) on a 4-point Likert system and the testretest reliability level for the entire scale was found as .72. For the similar scale validity study, this Quality of Relationship Inventory was correlated with Interpersonal Relationship Scale, which is also used to measure the quality of relationships (Karakurt, 2001). As a result of correlation analysis, these two scales were found as correlated at average level $(r=.64, p=000)$. Moreover, significant correlation 
Özabac1, N., \& Erylmaz, A. (2015). The sources of self-esteem: Initating and maintaining romantic intimacy at emerging adulthood in Turkey. International Journal of Human Sciences, 12(1), 178-191. doi: $\underline{10.14687 / \text { ijhs.v12i1.3014 }}$

among the sub-dimensions of these scales was detected. For the present study and participants, the reliability level for the entire scale was found as .71 for the sub-dimensions; for social support it was .77 ; for the depth it was .78, and; for the conflict sub-dimension it was found as .65 .

\section{Results}

The findings of the study are dealt with by three main titles. Firstly, the findings of correlation analysis, then multiple regression results are presented.

\section{Examining the Correlation between Dependent and Independent V ariables: The Results of Pearson Correlation}

The correlation between the variables was analyzed through Pearson Correlation Test. The obtained findings are presented on Table 1 following:

Table 1.The Findings of Pearson Correlation on the Dependent and Independent Variables

\begin{tabular}{|c|c|c|c|c|c|c|c|c|c|}
\hline Variables & 1 & 2 & 3 & 4 & 5 & 6 & 7 & 8 & 9 \\
\hline 1. Self-esteem & 1 & ,30** &, $32^{* *}$ & ,34** & ,24** & ,08 &,- 08 & $10^{*}$ & $14^{*}$ \\
\hline 2. Self-perception & & 1 & $60^{* *}$ &, $54 * *$ & $21 * *$ &, $39 * *$ &, $10^{*}$ & 06 & $10^{*}$ \\
\hline 3. Behavioral Intimacy & & & 1 &, $62^{* *}$ &, $26^{* *}$ & ,49** &, 00 & 03 & ,02 \\
\hline $\begin{array}{l}\text { 4.Emotional and Cognitive } \\
\text { Intimacy }\end{array}$ & & & & 1 &, $26^{* *}$ & ,43** &,- 00 & 08, & 01, \\
\hline 5.Self-knowledge & & & & & 1 & ,24** &, $11 *$ & ,25** &, $11 *$ \\
\hline 6. Romantic Verbalization & & & & & & 1 & ,02 &, $13^{*}$ &,- 00 \\
\hline 7. Conflict & & & & & & & 1 &, $49^{* *}$ & ${ }^{-}$, \\
\hline $\begin{array}{l}\text { 8. Social Support } \\
\text { 9. Depth }\end{array}$ & & & & & & & & 1 & $\begin{array}{r}, 51 * * \\
1 \\
\end{array}$ \\
\hline
\end{tabular}

The findings of Pearson Correlation analysis on Table 1 indicate that with the exception of the markers of self-esteem and romantic verbalization, there is a significant positive but low correlation between other markers and the sub-dimensions of quality of relationship, namely social support and depth.

\section{The Results of Multiple Regressions}

The regression analysis among self-esteem and the markers of starting romantic intimacy and quality of relationship were examined through multiple regression analysis. The related findings are given on Table 2:

Table.2.The Findings of Multiple Regression Analysis

B SEB Beta $\mathrm{t}$ p 
Özabac1, N., \& Erylmaz, A. (2015). The sources of self-esteem: Initating and maintaining romantic intimacy at emerging adulthood in Turkey. International Journal of Human Sciences, 12(1), 178-191. doi: 10.14687/ijhs.v12i1.3014

\begin{tabular}{lccccc}
\hline Self-perception &, 31 &, 14 &, 14 & 2,11 &, $03 *$ \\
$\begin{array}{l}\text { Behavioral Intimacy } \\
\text { Emotional and Cognitive }\end{array}$ &, 35 &, 17 &, 15 & 2,06 &, $04^{*}$ \\
Intimacy &, 50 &, 17 &, 20 & 2,90 &, $00 * *$ \\
Self-knowledge &, 48 &, 17 &, 15 & 2,76 &, $00 * *$ \\
Romantic Verbalization &,- 38 &, 13 &,- 17 & $-2,92$ &, $00^{* *}$ \\
Conflict &,- 50 &, 13 &,- 22 & $-3,77$ &, $00 * *$ \\
Social Support &, 18 &, 14 &, 08 & 1,33 &, 18 \\
Depth &, 35 &, 14 &, 14 & 2,41 &, $01 *$ \\
\hline
\end{tabular}

$* * p<0.01$, Not: $* p<0,05$

When the figures on Table 2 are examined $\left(\mathrm{R}=.49 ; \mathrm{R}^{2}=.24 ; \mathrm{F}=11,36 ; p<0.01\right)$, it can be seen that at regression equation mostly conflict $(\beta=-.22 ; p<0.01)$, then emotional and cognitive intimacy $(\beta=.20 ; p<0.01)$, romantic verbalization $(\beta=-.17 ; p<0.01)$, self-knowledge $(\beta=.15 ; p<$ $0.01)$, behavioral intimacy $(\beta=.15 ; p<0.04)$, depth $(\beta=.14 ; p<0.01)$ and self-perception $(\beta=.14 ; p$ $<0.03)$ explain the emerging adults' self-esteem levels at a significant level.

According to regression analysis results, with the exception of conflict and romantic verbalization, the other factors could explain self-esteem positively. These results indicate that the related variables explain $24 \%$ of variation of starting romantic intimacy.

\section{Discussion and Conclusion}

The present study examined the initiating and maintaining of romantic intimacy as the sources of self-esteem. According to the results, emerging adults perceived both having the markers of starting romantic intimacy and positive quality of relationship as significant sources for their selfesteem.

Related studies and literature review also indicate that with romantic relations, the emerging adults become happier when they provide social support to each other, they experience fewer conflicts and their commitment levels are higher. In other words, having positive quality of relationship, individuals receive psychologically more positive emotions (Corcoran \& Fischer, 2000; Sprecher \& Hendrick, 2004). While the significance of self-esteem for romantic relations has been the main focus in literature (Chain, 1988; Cramer, 1993; Hally \& Pollack, 1993; Meador \& Rogers, 1979), conversely, the importance of romantic relations for self-esteem has been neglected. This 
Özabac1, N., \& Eryılmaz, A. (2015). The sources of self-esteem: Initating and maintaining romantic intimacy at emerging adulthood in Turkey. International Journal of Human Sciences, 12(1), 178-191. doi: $\underline{10.14687 / \text { ijhs.v12i1.3014 }}$

study revealed that in parallel with positive quality of relationship, the self-esteem level increases, thus it was emphasized that romantic relations are important sources for self-esteem.

Additionally, in the literature, the concepts of self-perception and self-knowledge, which are derived from the markers of starting romantic intimacy, have been found to have a positive relationship with an individual's self-esteem (Eryllmaz \& Atak, 2011). Accordingly, the present study revealed that four markers of starting romantic intimacy, with the exception of romantic verbalization, explain the self-esteem level significantly. When the contents of related markers are examined, it could be observed that these markers are positive factors that enable individuals to start romantic intimacy (Eryllmaz \& Atak, 2009; Eryılmaz \& Ercan, 2010; Eryılmaz \& Atak, 2011). Thus, even the least significant life experience is enhanced and useful for both personal development and to provide opportunities for the others' development (Prager, 1995). In that sense, self-esteem is a crucial factor that develops at the relationship level. The present study showed that the factors that make relationships a more positive experience also mediate to develop an individuals' self-esteem in a positive way.

Moreover, in the present study, it was seen that romantic verbalization influenced the individuals' self-esteem negatively. An underlying reason for this finding could be the overuse of this marker causing an individual to idealize to the extreme both the relationship and the partner. Meaningful expression and the reading of poems to a partner consistently could attribute more value than necessary to a partner. An individual whose self-esteem is at optimal levels is realistic. Self-esteem that is under or over the optimal level could be a cause for pathological patterns such as narcissism (Baumeister et al., 2003; Baumeister, Smart, \& Boden, 1996; Donnellan et al., 2005; Webster, 2007). These assumptions could explain the finding of significant negative correlations between the markers of romantic verbalization.

Several important limitations should be considered when interpreting the results of our study. One of the limitations of this study was that during the data collection process, we may have limited with the only the participants' responses that we accept they answer intentionally. The other limitation is that, the study group doesn't include less educated emerging adults, meaning that the forgotten half was excluded (Arnett, 2001).

Despite limitations, this study has a number of strengths. Our research breaks new ground in the study of emerging adulthood romantic development. We have shown that the common experience of a romantic termination can be explained with reference to meaningful developmental principles, goodness-of-fit, and continuity with salient romantic needs. The use of appropriate questionnaires provided valuable information regarding emerging adults' self-esteem and the 
Özabac1, N., \& Erylmaz, A. (2015). The sources of self-esteem: Initating and maintaining romantic intimacy at emerging adulthood in Turkey. International Journal of Human Sciences, 12(1), 178-191. doi: $10.14687 /$ ijhs.v12i1.3014

markers of starting romantic intimacy and relationship quality. Using these questionnaires the study has provided further insight into emerging adults' experience about identity exploration of love.

The results of the present study emphasized the significance of self-esteem for both initiating and maintaining romantic intimacy. Further qualitative and quantitative studies on the development of self-esteem during the process of starting and maintaining romantic intimacy could be conducted with psychological counselors, parents and educators. Moreover, related to the concept of self-esteem, supporting studies with parents and psychological counselors at educational institutions could also be carried out.

\section{References}

Arnett, J. J. (2000). Emerging adulthood: A theory of development from the late teens through the twenties. American Psychologist, 55, 469-480. http://dx.doi.org/10.1037/0003$\underline{066 X .55 .5 .469}$

Arnett, J. J. (2001). Conceptions of the transition to adulthood: Perspectives from adolescence to midlife. Journal of Adult Development, 8, 133-143. http://dx.doi.org/10.1023/A:1026450103225

Arnett, J. J. (2004). Emerging adulthood: The winding road from the late teens through the twenties. New York: Oxford University Press. http://dx.doi.org/10.1093/acprof:oso/9780195309379.003.0010.

Baumeister, R. F.; Campbell, J. D.; Krueger, J. I.; Vohs, K. D. (2003). "Does High Self-Esteem Cause Better Performance, Interpersonal Success, Happiness, or Healthier Lifestyles?". Psychological Science in the Public Interest 4 (1): 1-44. http://dx.doi.org/10.1111/1529$\underline{1006.01431}$

Baumeister, Roy F., Smart, L. \& Boden, J. (1996). "Relation of threatened egotism to violence and aggression: The dark side of self-esteem". Psychological Review, 103, 5-33. http://dx.doi.org/10.1037/0033-295X.103.1.5

Bradbury, T.N. Cohan, C.L. \& Karney, B.R. (1998). Optimizing longitudinal research for understanding and preventing marital dysfunction. In: T.N. Bradbury, Editor, The developmental course of marital dysfunction, Cambridge University Press, New York . http://dx.doi.org/10.1017/CBO9780511527814.011

Brown, B.B. ; Feiring,C. and Furman, W. (1999) Missing the love boat: Why researchers have shied away from adolescent romance. In: W. Furman, B.B. Brown and C. Feiring, Editors, The development of romantic relationships in adolescence, Cambridge University Press, New York pp. 1-18. http://dx.doi.org/10.1017/CBO9780511551963.016

Cain, D. (1988). Divorce among elderly women: A growing social phenomenon. Social Casework, 69, 563-568. Casper, L. M., \& Bianchi, S. M. (2002). Continuity and change in the american family. Thousand Oaks: Sage. http://dx.doi.org/10.1017/CCOL052184648X.004

Collins, W.A. \& Sroufe, A.(1999),.Capacity for intimate relationships: a developmental construction W. Furman, B. Brown, C. Feiring (Eds.), The development of romantic relationships in 
Özabac1, N., \& Erylmaz, A. (2015). The sources of self-esteem: Initating and maintaining romantic intimacy at emerging adulthood in Turkey. International Journal of Human Sciences, 12(1), 178-191. doi: $10.14687 /$ ijhs.v12i1.3014

adolescence, Cambridge University Press, NY pp. 125-147. http://dx.doi.org/10.1097/00042192-199902040-00032

Connely, J., \& Goldberg, A. (1999). Romantic relationships in adolescence: The role of friends and peers in the emergence and developmant. In W. Furman, B. B. Brown, \& C. Feiring, (Eds.), The development of romantic relationships in adolescence (pp. 266-290). Cambridge, UK: Cambridge University Press. http://dx.doi.org/10.1002/9780470479193.adlpsy002005.

Corcoran, K., \& Fischer, J. (2000). Measures for clinical practice: A sourcebook (1). New York, NY: The Free Press. http://dx.doi.org/10.5014/ajot.61.1.7

Collins,W.A. \& Steinberg, L. (2006). Adolescent development in interpersonal context N. Eisenberg, W. Damon, R.M. Lerner (Eds.), Handbook of child psychology: Vol. 3. Social, emotional, and personality development (6th ed.), John Wiley, NY (2006), pp. 1003-1067. http://dx.doi.org/10.1002/9780470147658.chpsy0316.

Cramer, D. (1993). Perceived and desired facilitativeness of one's closest friend, need for approval and self-esteem. British Journal of Medical Psychology, 66, 97-104. http://dx.doi.org/10.1111/j.2044-8341.1993.tb01731.x

Cramer, D. (2009). Self-esteem, demand for approval and the facilitativeness of a romantic relationship. British Journal of Guidance \& Counselling, 37 ( 2), 169-178. http://dx.doi.org/10.1080/03069880902728606

Donnellan, B., Fitzgerald, B., Lake, B. \& Sturdy, J. (2005) Implementing an Open Source Knowledge Base. IEEE Software, 22(6), 92-95. http://dx.doi.org/10.1109/MS.2005.155

Eryllmaz and Atak (2011). Investigation of Starting Romantic Intimacy in Emerging Adulthood in terms of Self-Esteem, Gender and Gender Roles Kuram ve Uygulamada Eğitim Bilimleri Educational Sciences: Theory \& Practice - 11(2) 595-600.

Eryllmaz, A., \& Atak, H. (2009). Ready or not? Markers of starting romantic intimacy at emerging adulthood: Turkish experience. International Journal of Social Science, 4 (1), 31-38.

Feiring, C. (1996) Concepts of romance in 15-year-old adolescents. Journal of Research on Adolescence, 6 , 181-200. http://dx.doi.org/10.1007/BF01993439

Fischer, C.T. \& Alapack, R.A. (1987). A phenomenological approach to adolescence. In: L. van Hassellt, Editor, Handbook of adolescence psychology, Wiley, New York , pp. 9110http://dx.doi.org/10.1097/00004703-199402000-000169.

Fisher, H.E (1998) Lust, attraction, and attachment in mammalian reproduction, Human Nature 9, pp. 23-52. http://dx.doi.org/10.1007/s12110-998-1010-5.

Fisher, H.E. (2006). Broken hearts: The nature and risks of romantic rejection. In: A.C. Crouter and A. Booth, Editors, Romance and sex in adolescence and emerging adulthood: Risks and opportunities, Erlbaum, Mahwah, NJ, pp. 3-28. http://dx.doi.org/10.1007/s12110-998-1010-5.

Fisher, H.E. ,Aron,A.. Mashek, D. Li,H. and Brown, L.L. (2002). Defining the brain systems of lust, romantic attraction, and attachment, Archives of Sexual Behavior 31 , pp. 413-419. http://dx.doi.org/10.1023/A:1019888024255.

Furman, W., \& Schaffer, L. (2003). The role of romantic relationships in adolescent development. In P. Florsheim (Ed.), Adolescent romantic relations and sexual behavior: Theory, Research, and practical implications (pp. 4-22). Mahwah, NJ: Erlbaum. http://dx.doi.org/10.1017/CBO9780511551963.016. 
Özabac1, N., \& Erylmaz, A. (2015). The sources of self-esteem: Initating and maintaining romantic intimacy at emerging adulthood in Turkey. International Journal of Human Sciences, 12(1), 178-191. doi: $10.14687 /$ ijhs.v12i1.3014

Furman, W. ; Brown, B.B. and Feiring, C. (1999) The development of romantic relationships in adolescence, Cambridge University Press, New York.http://dx.doi.org/10.1017/CBO9780511551963.016

Furman,W \& Wehner,E.A. (1994) Romantic views: towards a theory of adolescent romantic relationships. R. Montemayor, G.R. Adams (Eds.), Personal relationships during adolescence, Sage, CA pp. 168-195. http://dx.doi.org/10.1017/CBO9780511551963.016

Furman,W and Wehner, E.A. (1997) Adolescent romantic relationships: A developmental perspective. In: S. Shulman and W.A. Collins, Editors, Romantic relationships in adolescence: Developmental perspectives, Jossey-Bass, San Francisco, pp. 21-36. http://dx.doi.org/10.1017/CBO9780511551963.016

Gottman, J.M. \& Levenson, R.W. (2000). The timing of divorce: Predicting when a couple will divorce over a 14-year period, Journal of Marriage and the Family 62, pp. 737-745. http://dx.doi.org/10.1111/j.1741-3737.2000.00737.x

Gray, M.R. \& Steinberg, L. (1999). Adolescent romance and parent-child relationship: A contextual perspective. In: W. Furman, B.B. Brown and C. Feiring, Editors, The development of romantic relationships in adolescence, Cambridge University Press, New York, pp. 235-265. http://dx.doi.org/10.1016/B978-0-12-375000-6.00003-3

Hally, C. R., \& Pollack, R. (1993). The effects of self-esteem, ariety of sexual experience, and erotophilia on sexual satisfaction in sexually active heterosexuals. Journal of Sex Education and Therapy, 19, pp. 183-192. http://dx.doi.org/10.1097/00006199-199607000-00007

Hatfield, E. (1988) Passionate and companionate love R.J. Sternberg, M.L. Barnes (Eds.), The psychology of love, Yale University Press, CT ,pp. 191-217. http://dx.doi.org/10.1300/J056v01n01 04

Hinde, R.A(1997) Relationships a dialectical perspective, Psychology Press, Hove, East Sussex. http://dx.doi.org/10.1111/j.1475-6811.1997.tb00074.x

Karakurt,G. (2001) The Impact of adult attechment styles on romantic jeaolusy, Unpublished Master Thesis. METU Ankara.

Laursen, B. (1993). The perceived impact of conflict on adolescent relationships, Merrill-PalmerQuarterly 39, pp. 535-550. http://dx.doi.org/10.1207/s15327795jra0501 3

Meador, B. D., \& Rogers, C.R. (1979). Person-centered therapy. In R.J. Corsini clinical assesment instruments. Psychological Assessment,7, pp.286-299.(Ed.),Currentpsychotherapies (pp. 131184). Itasca, IL: Peacock.New York: Mcgraw-Hill. http://dx.doi.org/10.1001/jama.1992.03490010037012

Özabac1, N (2011) . The Development of Relationship Quality Scale. Eğitim ve Bilim (Education and Science) 36 (162) .

Perry, D.G., Perry,L.C. \& Kennedy, E. (1992). Conflict and the development of antisocial behavior. In: C.U. Shantz and W.W. Hartup, Editors, Conflict in child and adolescent development, Cambridge University Press, New York . http://dx.doi.org/10.1111/j.1467954X.1974.tb00508.x

Pettijohn, T. F., Naples, G. M., \& McDermott, L. A. (2010). Gender, college year, and romantic relationship status differences in embarrassment and self attitudes of college students. $I n$ $\begin{array}{lllll}\text { dividual Differences } & \text { Research, } & 8 & \text { (3), } & \text { pp. }\end{array}$ http://dx.doi.org/10.4236/psych.2011.22012 
Özabac1, N., \& Erylmaz, A. (2015). The sources of self-esteem: Initating and maintaining romantic intimacy at emerging adulthood in Turkey. International Journal of Human Sciences, 12(1), 178-191. doi: $10.14687 /$ ijhs.v12i1.3014

Rosenberg, M. (1965). Society and the adolescent self-image. Princeton University Press. http://dx.doi.org/10.1145/276755.276768

Sanderson, C.A. and Cantor, N. (1995)Social dating goals in late adolescence: implications for safer sexual activity, Journal of Personality and Social Psychology 68 pp. 1121-1134. http://dx.doi.org/10.1037/0022-3514.68.6.1121

Scharff, J.S. \& Scharff, D.E. (2004). Object relations couple therapy, American Journal of Psychotherapy 51 (141), p. 173. http://dx.doi.org/10.1002/aps. 72

Selman, R.L. (1980). The growth of interpersonal understanding: Developmental and clinical analyses, Academic Press, New York. http://dx.doi.org/10.1016/0273-2297(81)90034-4

Shaver,P. ,Hazan,C and Bradshaw, D. (1988) Love as attachment: The integration of three behavioral systems. In: R.J. Sternberg and M. Barnes, Editors, Anatomy of love, Yale University Press, New Haven, CT pp. 68-99. http://dx.doi.org/10.1111/j.14756811.1996.tb00105.x

Shulman, S.; Mayes, L.C., Cohen, T.H.; Swain,J.E. and Leckman, J.F.(2008). Romantic attraction and conflict negotiation among late adolescent and early adult romantic couples . Loumal of Adolescence, 31, (6), pp.729-745. http://dx.doi.org/10.1016/j.adolescence.2008.02.002

Shulman,S \& Scharf, M. (2000) Adolescent romantic behaviours and perceptions: age-related differences and links with family and peer relationships. Journal of Research on Adolescence, 10 pp. 99-118. http://dx.doi.org/10.1207/SJRA1001 5

Sprecher, S.\& Hendrick, S. (2004). Self -disclosure in intimate relationships: Associations with individualand relationship characteristics over time. Journal of Social and Clinical Psychology, 23, 836-856. http://dx.doi.org/10.1521/jscp.23.6.857.54803

Tolman,D.L. (2002) Dilemmas of desire: teenage girls talk about sexuality Harvard University Press, MA . http://dx.doi.org/10.1300/J015V11N03 04

Webster, G. D. (2007). Is the relationship between self-esteem and physical aggression necessarily U-shaped? Journal of Research in Personality, 41, 977-982. http://dx.doi.org/10.1016/j.jirp.2007.01.001 